\title{
O Herói (The Hero) and the Post-Colonial Angolan State
}

\author{
Bonnie Wasserman \\ University of Arizona, Arizona, USA
}

\begin{abstract}
This article examines how post-war Angola is depicted in the film O Herói (The Hero). With a well-known international cast and funding from a number of foreign sources, this movie heralds in a new era for Lusophone African cinema. Director Zezé Gamboa highlights the difficult reality faced by those living in Luanda, the capital of Angola, with scenes of water and electricity shortages, unemployment, and gang violence. He also touches upon some of the themes from the work of famed Senegalese author and director Ousmane Sembène such as corruption and neo-colonialism. One of the very few Angolan movies that has been shown at international festivals and theaters, O Herói (2004) not only offers a harsh portrayal of living conditions after 40 years of conflict, especially that of the treatment of disabled veterans injured in the mine fields that still are found throughout the country, but also creates a sense of hope for families displaced by war to be reunited or at least form new bonds in the future.
\end{abstract}

Keywords: Angola, cinema, civil war, post-colonialism, post-war reconstruction, Neo-colonialism, Africa

\section{Introduction}

The 2004 film $O$ Herói (The Hero) by Zezé Gamboa delves into the difficulties faced by post-combatants as well as civilians of the Angolan colonial and civil wars living in the capital of Luanda. The film won the Jury Prize at the 2005 Sundance Film Festival - a first for Lusophoneor Portuguese-African Cinema. The main plot revolves around a veteran aptly named Vitório (Victory) played by the Senegalese actor Makena Diop who lost a leg in the war and the difficulty he faces obtaining a prosthetic limb and then recovering it after it is stolen. The film's subplots include the every day challenges Angolans struggle with living in a post-colonial, post-war state including finding work, obtaining water and searching for lost relatives. This article focuses on the transnational aspects of the film such as the use of international actors and themes from foreign cinemas as well as the impact of war on women and children in post-colonial Africa.

Before independence, cinema was used to convert the Africans as well as depict them as subservient to whites (Davidson, 1983). During the early post-colonial era, in some countries African directors had a difficult time making their own projects due to lack of training as well as materials. Some went overseas to Cuba and France to learn basic film making skills and in later years needed the assistance of overseas financing as well as the integration of foreign stars to attract audiences, both foreign and domestic. The development of Lusophone-African cinema was severely affected by years of colonial control from the Portuguese, a lengthy liberation conflict, decades of civil war fought by Cold War proxies, and difficulties in establishing an operative post-colonial and post-war state. Few films from the five Portuguese-speaking African nations were produced and appeared on international screens with the exception of $O$ Testamento do SenhorNapomuceno (Napomuceno's Will) in 1997 directed by Francisco Manso, the 1998 Cape Verdean Fintar o destino 
(Dribbling Fate) by Fernando Vendrell and Udju Azul di Yonta (The Blue Eyes of Yonta) in 1992 by Guinea Bissauan director Flora Gomes. Angola had a more difficult time producing films as the Civil War lasted well into the mid-1990s. In the waning years of the conflict and the initial decades of a post-war government two notable films were released: the 1991 Na CidadeVazia (Hollow City) by João Gamboa and O Herói (The Hero) directed by Zezé Gamboa in 2004. The latter movie in particular can be viewed as initiating a new era in Angolan film making, with the inclusion of transnational assistance.

In the case of Angola, the situation was made much worse by ongoing wars that lasted long after independence in 1975. Initially there were three opposing groups that fought against the Portuguese: the FNLA, the National Liberation Front of Angola, National Union for the Total Independence of Angola (UNITA) supported by the United States and South Africa and the Popular Front For the Liberation of Angola (MPLA) backed by the former USSR. After Independence, the FNLA and UNITA eventually joined forces and brutally fought against the MPLA. Only after the death of Jonas Savimbi, the head of UNITA, in 2002 and the signing of the Luena Agreement did the conflict formally end. Following the civil war, the establishment of a functional new government was extremely difficult. There was still animosity between the former combatants, and the country was left in a state of disarray on all levels. David Murphy and Patrick Williams explain that, "various urgent tasks of construction and reconstruction, both infrastructural and super-structural, constitute the immediate postcolonial agenda" (p. 14). After nearly 40 years of conflict, including the colonial battles for independence, tens of thousands were dead and displaced, innumerable unmarked land mines were buried throughout the countryside, and the government had enormous complications supplying basic necessities such as water, sewage and electricity.

Though the physical danger of making feature films was no longer present in post-war Angola, other issues such as subsidizing them and finding skilled actors would still prove to be problematic. It is at this time that transnational film production assisted with the complications faced by making movies such as $O$ Herói. In transnational cinema, there are companies and professionals from more than one country involved in making a film. Outside crews assist with cinematic techniques and material not available in a given country. Moreover, international cast members bring "star power" that helps market the film on a more widespread and global level. As Deborah Shaw (2013) notes,

The notion of the transnational in Film Studies has developed in response to an increasing awareness of the limitations of conceptualizing film in terms of national cinemas, and an acknowledgement of the changing nature of film production and distribution as a part of wider market cannot be identified with a single nation, with many films shooting in a number of countries, relying on a multinational cast and crew, and funded by a range of production companies. (p. 47)

O Herói can be considered both a Lusophone-African film because its director is Angolan and it was filmed there but it is also transnational. Three foreign countries assisted with its production: France, Portugal, and Brazil. Of these, France can be considered to be the European country that has most fueled incipient film industries in African countries. This nation has always been interested in maintaining its own cultural and economic base in its former colonies and there are many excellent examples of Francophone African films. Portugal is also interested in maintaining its cultural and economic ties with its former colonies, especially in the case of mineral and oil rich Angola. In the case of Brazil, there is a growing interest in its Afro-Brazilian history and culture and this South American country exports its own cultural productions in the form of telenovelas or soap operas. 
In addition to the international assistance in producing $O$ Heró $i$, the cast includes a number of non-Angolan actors. Makena Diop, a Senegalese actor, interprets the main character Vitório. Maria Ceiça, a Brazilian actress, plays the role of the prostitute Maria Barbara whose nome de guerre (alias) is Judite. Portuguese actress Patricia Bull plays Joana, the teacher of the young boy, Manu. Whereas Diop's interpretation of Vitório's painful and frustrating predicament has been applauded for its subtle nuances, Ceiça has been attacked by a number of critics for her acting. According to Sabine (2011), "Ceiça in particular struggles to modify her Brazilian accent, and moreover maintains the hyperbolically expressive and emotive acting conventions of telenovela in a manner that occasionally jars with the understated performances of Makena Diop and the Angolan actors" (p. 205). In one particular scene, the Brazilian actress appears to stand out uncomfortably. At the "Ponto de Re-encontro" or "Meeting Place" Angolans are filmed making appeals to their relatives lost during the wars. The meeting place is an actual space for Angolans to reach out to their lost ones with the hope that they are still alive. According to Jordan Boslego (2005), the number of missing Angolans is enormous: "Many of the estimated four million internally displaced persons and 440, 000 refugees who sought asylum in bordering countries during the conflict have yet to return to their homes" (p. 6). Attempting to bring lost family members together brings credibility to the governmentas it attempts to make a fracture society whole again. Ceiça appears too emotional when making her trying to find her son who was lost during the war compared to the more serious and long-suffering Angolans.

Though this actor may also seem "too Brazilian" for an Angolan film such as O Herói with her South American accent and soap opera acting, her casting reflects a number of decisions ranging from marketing to a wider audience and acceptance of new standards of Portuguese usage eliminating written differences between the language in the Países Africanos de LinguaOficial Portuguesa [(Portuguese-speaking African Countries) (PALOPs)]. Due to the popularity of Brazilian telenovelas or soap operas, Portuguese speakers the world over understand the Brazilian accent easier than Brazilians understand Continental or African accented Portuguese and would not have a problem identifying Ceiça as a Brazilian in an Angolan role.

She is also believable as a character of a female war survivor: "Long-term exposure to war and postwar stressors caused serious psychological consequences in civilian women, with Post Traumatic Stress Disorder (PTSD) being only one of the disorders in the wide spectrum of posttraumatic reactions" (Klaric, 2007, p. 167). Angolan women had a more difficult time during the wars because they were taken advantage of and at times abused. Judite's emotional performance reflects how those in a post-war and possible post-traumatic situation would normally react. According to Da Silva (2011),

Her role implies that although women struggled and suffered throughout the wars they continue to be marginalized and exploited by a patriarchal machistic society in the aftermath. During the war, women were more often undervalued and even if they were enrolled in the army they were not seen as key players in the war and received little recognition for their struggle in the conflicts. (p. 195)

Another international actress that has not been critiqued but is somewhat problematic is Joana played by the Portuguese actor Patricia Bull. Joana seems to pose an enigma to several scholars. In some articles about the film she is referred to as an Angolan woman who stayed behind after her father, a high-ranking MPLA official, left for Lisbon. In other articles she is an upper class Portuguese mixed race person or mestiza who wishes to improve society as a schoolteacher, only to be frustrated by the strikes that teachers are forced to wage against the government. Her dedication to help her young student Manu continue with his studies and stay out of 
trouble is admirable as is her willingness to help Vitório get his prosthesis back by convincing the nephew of the Minister of the Interior to make an appeal on the radio. Yet, Joana's character stands out for her striking good looks far more than Ceiça. Though many Angolans are of mixed race and can have very light colored skin and eyes - she does not seem to fit in with the Angolan actors around her. Joana also seems to vacillate between her affections for Pedro, the Minister's nephew who has returned from overseas to take a job in the government. At first, she seems turned off by his approaches and questions the apparent nepotism in the Angolan administration in which he will get a job with his uncle in the government. However, she lets her guard down quickly and agrees to sleep with him almost too soon after repelling him. This behavior seems somewhat out of character for her high morals as a teacher and a role model. However, her inclusion in the film may be due to the influence of a male director's casting choice, assuming that this beautiful actress and her love affair fulfills her wish to help Vitório get his prosthetic leg back by "convincing” the minister's nephew to help him.

In addition to these forms of transnational financing and actors, $O$ heró $i$ has been heavily influenced by "the Father of African film", Senegalese author and director, Sembene Ousmane (1923-2007). Ousmane made numerous films focusing on issues related to post-colonialism and neocolonialism. Gamboa's film resembles that of Ousmane's work not only in terms of subject matter, but also in structure. According to Harrow (2007),

Ousmane's films begin with the presentation of a problem, usually involving a crisis that crystalizes around some opposition to the film's protagonist. This is usually followed by a false solution in which the prospects of the removal of the obstacle are shown to be inadequate. Eventually a true solution is found, with the issues related to the film's underlying rhetoric resolved and explicated. (p. 1)

In the case of $O$ Herói, the film begins with the difficulty faced by Vitório obtaining a prosthetic leg and contributing to society as an "able" worker. He cannot find a job when he finally receives the leg he feels better about himself, even selling his crutches for nicer clothes to fit in socially without his army fatigues. When the leg is stolen he becomes despondent and humiliated, especially at a bar. Only when he gets his leg back does he find a new home with a woman and an "adoptive" son.

Of Ousmane's films most similar to $O$ Herói and its portrayal of post-colonialism and neocolonialism is Xala (1974). Though it was made over 30 years before, O Herói, Xala depicts a newly independent African nation that immediately falls into the grips of neocolonialism. The African elite are shown taking money from the French, who never truly leave the country after Independence. The same can be implied in postcolonial Angola. In one scene, Vitório seeks a job at a construction site and begs to speak to the manager. When the Angolan manager appears, he points to a white Portuguese man and says that he is the one who is truly in charge leaving one to believe that the reconstruction of the city is in the hands of those who once had a part in its destruction.

Another instance in which the two films are somewhat similar are in their depiction of power through phallocentrism. According to Harrow (2007), "phallocentrism has come to stand for many things: sexism, heterosexism, the association of authority with male power... and eventually, symbolic or imaginary the threat of castration" (p. 50). In Xala, El-Hadji is cursed with impotence when he treats a beggar poorly. Not being able to "perform" on his wedding night with his young third wife leaves the older, wealthy man humiliated. In order to recover his manhood he loses his family, fortune and status in society. The case is not exactly the same in The Hero, yet Vitório's loss of his leg and his inability to find work or a woman at a bar makes him feel less 
of a man. For Sabine (2011), "The film modifies the conventional metonym, focusing on the loss of the prosthesis, rather than of Vitório's original leg, as symbolic castration, and thereby avoiding a simplistic analogy between disability and emasculation" (p. 210). Sabine is careful to state that being disabled by stepping on a mine is the not the equivalent of being less than a man given the huge number of land mine amputees, but in the movie Vitório is indeed emasculated by the dancers and prostitutes at the bar who take advantage of him by stealing his money and laughing at him when he cannot get up after being knocked down. Being "whole" in terms of performance in bed and providing for oneself and a family are essential to a man's sense of self as is the ability to contribute to a post-colonial state.

Cars are also symbolic of masculine power and associated with the elite class in the post-colonial state in both movies. The politicians and their relatives in Xala and $O$ Heró $i$ are driven around in fancy cars that the ordinary public could never afford. The disdain showed towards the poor by the elite in their automobiles is depicted in $O$ Heroi when a child is run over by the Interior Minister's nephew. Rather than taking the youngster to the hospital, Pedro prefers to leave him in the road. It is only through the insistence of Joana that the child is brought to the hospital where the attractive woman waits outside all night until he is eventually seen by a doctor.

The role of children and their participation in gangs not only reflects an unfortunate reality of post-colonial post-war Luanda, but it depicts a major trope in other Third Cinema such as that in Brazil. Through the filmic representation of Luanda in Maria João Ganga's Hollow City (2004) and Zezé Gamboa's The Hero (2004), Antonio Marcio da Silva describes how decades of wars forced the migration or scattering of thousands of Angolans fleeing the fighting. Many of the migrants were children who were obliged to fight like Vitório at age 15 or separated from their parents like Judite's child. Numerous youngsters ended up living without families in the shantytowns or musseques of big cities like Luanda. There they organized themselves into gangs that served as pseudo-families and live by petty crime. In the beginning of the movie, the young people steal a bicycle and trade parts of stolen material with a man who runs a junk store.

The portrayal of children in Angolanshanty towns is much like that of the gangs in the Brazilian favelas featured in films such as City of God (2002) by Fernando Meireles and Katia Lund and Bus 174 (2002) by José Padilha. Just as $O$ Herói begins with a broad aerial sweep of the musseques, Bus 174 begins with a view of Rio's favelas from the sky. In $O$ Herói, a group of boys plays basketball, but the game turns violent when Manu, a young boy who lives with his grandmother, accidently hits the leader of the gang much like the sociopathic character ZéPequeno who runs the drug trade in City of God. In both Angolan and Brazilian films, the battles over gang turf are reminiscent of the Civil Wars fought by their fathers, brothers and uncles.

$O$ Herói draws from transnational sources and themes and provides a realistic view of life in a society that is coming to terms with years of brutal conflict. The harsh reality of veterans living in a post-war environment where they are not valued nor given the care they need is brought to light. Both men and women suffer in war-men through the symbolic castration of being amputees and women being reduced to using their bodies to make a living. Children, most of all, must live with the unknown of where their parents are and deal with finding dangerous pseudo-families amongst gangs on the streets. There is hope, however, in the end as Vitório finally does receive his stolen prosthetic leg and a new, albeit somewhat forced, family is formed between him and Judite. 


\section{References}

Arenas, F. (2011). Lusophone Africa: Beyond independence. Minneapolis: Minnesota UP.

Boslego, J. (2005). Angola's Agony: Tenuous times post-Civil War. Harvard International Review, 26(4), 6.

Csaky, M., \& Davidson, B. (1983). Africa: A voyage of discovery with Basil Davidson. Episode 5: The Bible and the Gun.

Da Silva, A. M. (2011). Viewing the Angolan experience of war and peace through the filmic representation of Luanda in Maria João Ganga's Na CidadeVazia/Hollow City (2004) and Zeze Gamboa's OHerói/The Hero (2004). Journal of African Cinemas, 3(2), 187-200.

Harrow, K. W. (2007). Postcolonial African cinema: From political engagement to postmodernism. Bloomington: Indiana UP.

Klarić, M., Klarić, B., Stevanovic, A., Grković, J., \& Jonovska, S. (2007). Psychological consequences of war trauma and postwar social stressors in women in Bosnia and Herzegovina. Croation Medical Journal, 48(2), 167-176.

Murphy, D., \& Williams, P. (2007). Postcolonial African cinema: Ten directors. Manchester: Manchester.

Sabine, M. (2011) Rebuilding the Angolan politic: Global and local projections of identity and protest in O Herói/The Hero (Zezé Gamboa, 2004). Journal of African Cinemas, 3(2), 201-219.

Shaw, D. (2013). Deconstructing and reconstructing "transnational cinema". In S. Dennison (Ed.), Contemporary hispanic cinema: Interrogating transnationalism in Spanish and Latin American film (p. 47 ). Woodbridge:Tamesis. 